\title{
Endosymbiotic and Host Proteases in the Digestive Tract of the Invasive Snail Pomacea canaliculata: Diversity, Origin and Characterization
}

\author{
Martín S. Godoy ${ }^{1,2}$, Alfredo Castro-Vasquez ${ }^{1,2,3}$, Israel A. Vega ${ }^{1,2,3 *}$ \\ 1 Instituto de Fisiología, Facultad de Ciencias Médicas, Universidad Nacional de Cuyo), Mendoza, Argentina, 2 Instituto de Histología y Embriología "Dr. Mario H. Burgos", \\ Consejo Nacional de Investigaciones Científicas y Técnicas, Mendoza, Argentina, 3 Instituto de Ciencias Básicas, Universidad Nacional de Cuyo, Mendoza, Argentina
}

\begin{abstract}
Digestive proteases of the digestive tract of the apple snail Pomacea canaliculata were studied. Luminal protease activity was found in the crop, the style sac and the coiled gut and was significantly higher in the coiled gut. Several protease bands and their apparent molecular weights were identified in both tissue extracts and luminal contents by gel zymography: (1) a $125 \mathrm{kDa}$ protease in salivary gland extracts and in the crop content; (2) a $30 \mathrm{kDa}$ protease throughout all studied luminal contents and in extracts of the midgut gland and of the endosymbionts isolated from this gland; (3) two proteases of 145 and $198 \mathrm{kDa}$ in the coiled gut content. All these proteases were inhibited by aprotinin, a serine-protease inhibitor, and showed maximum activity between $30^{\circ} \mathrm{C}$ and $35^{\circ} \mathrm{C}$ and $\mathrm{pH}$ between 8.5 and 9.5 . Tissue L-alanine- $\mathrm{N}$-aminopeptidase activity was determined in the wall of the crop, the style sac and the coiled gut and was significantly higher in the coiled gut. Our findings show that protein digestion in $P$. canaliculata is carried out through a battery of diverse proteases originated from the salivary glands and the endosymbionts lodged in the midgut gland and by proteases of uncertain origin that occur in the coiled gut lumen.
\end{abstract}

Citation: Godoy MS, Castro-Vasquez A, Vega IA (2013) Endosymbiotic and Host Proteases in the Digestive Tract of the Invasive Snail Pomacea canaliculata: Diversity, Origin and Characterization. PLoS ONE 8(6): e66689. doi:10.1371/journal.pone.0066689

Editor: Christopher R. Weber, University of Chicago, United States of America

Received January 28, 2013; Accepted May 8, 2013; Published June 20, 2013

Copyright: (C) 2013 Godoy et al. This is an open-access article distributed under the terms of the Creative Commons Attribution License, which permits unrestricted use, distribution, and reproduction in any medium, provided the original author and source are credited.

Funding: This work was supported by grants from the Universidad Nacional de Cuyo, Consejo Nacional de Investigaciones Científicas y Técnicas, and Fondo Nacional de Ciencia y Técnica (Argentina). The funders had no role in study design, data collection and analysis, decision to publish, or preparation of the manuscript.

Competing Interests: The authors have declared that no competing interests exist.

* E-mail: israel.vega7@gmail.com

\section{Introduction}

Pomacea canaliculata (Lamarck 1822) (Caenogastropoda, Ampullariidae) is a highly invasive apple snail original from Central and Northern Argentina, Southern Brazil and Uruguay, and that has spread to Southeast Asia, North America and Europe where it has become a plague for rice and other crops $[1,2,3]$.

Knowledge on the digestive tract of this polyphagous snail is essentially morphological and several specializations have been found [4] (Figure 1): (a) the buccal cavity receives the openings of a pair of salivary glands, (b) the esophagus has a pair of ventrolateral pouches and an expanded crop in its medial portion that retains food during digestion, (c) a three-chambered stomach, which comprises a muscular gizzard, a vestibule that receives the openings of the midgut gland and the style sac, (d) a thin gut, (e) a coiled gut, and (f) the rectum with an anal gland.

The epithelial cells of the midgut gland of $P$. canaliculata host two types of endosymbiotic pigmented corpuscles which are considered morphotypes of the same organism and are identified as $\mathrm{C}$ and $\mathrm{K}$ corpuscles $[5,6,7,8]$. The possible role of this endosymbiont in protein digestion was suggested by the unexpected finding of protease activity in extracts of $\mathrm{C}$ corpuscles isolated from the midgut gland of this snail (Vega, unpublished).

Proteolytic enzymes have been studied in vetigastropods (genera Haliotis and Megathura [9,10]), stylommatophoran pulmonates (genera Helix, Elona, Archachatina, Arion and Dermoceras
$[11,12,13,14]$ ), opistobranchs (genera Hermissenda and Aeolidia, [15]) and in an architaenioglossan (genus Viviparus [16]), but lack of proteases has been reported in the ampullariids Pila virens [17] and Pomacea canaliculata [4], the species which is studied here.

Hydrocarbon hydrolytic enzymes (endo-1,4- $\beta$-D-xylanase, $\alpha$ and $\beta$-mannosidase, $\beta$ - $\mathrm{N}$-acetylglucosaminidase, $\beta$-galactosidase and $\alpha$-fucosidase) have been purified from whole animal extracts of $P$. canaliculata $[18,19,20,21]$. Also, two cellulase cDNAs (GHF10Pcl and GHF10-Pc3) belonging to glycoside hydrolase family 10 (GHF10) were isolated and characterized from stomach tissue [22] but, to our knowledge, there is no available information about other enzymes that can participate in food digestion in this snail.

Here we studied (a) the occurrence, diversity and origin of host and endosymbiotic proteases in the digestive tract of $P$. canaliculata, (b) their sensitivity to different protease inhibitors, (c) their optimal $\mathrm{pH}$ and temperature ranges of activity, and (d) their cellular distribution in the midgut gland using in situ zymography.

\section{Materials and Methods}

\section{Animals and Culture Conditions}

Adult snails (shell length $35-40 \mathrm{~mm}$ ) from a cultured strain of $P$. canaliculata were used [8]. Room temperature was regulated (23$25^{\circ} \mathrm{C}$ ) and artificial lighting was provided $14 \mathrm{~h}$ per day. The animals were maintained in aquaria containing $2 \mathrm{~L}$ of tap water and the aquarium water was changed thrice weekly. Unless 


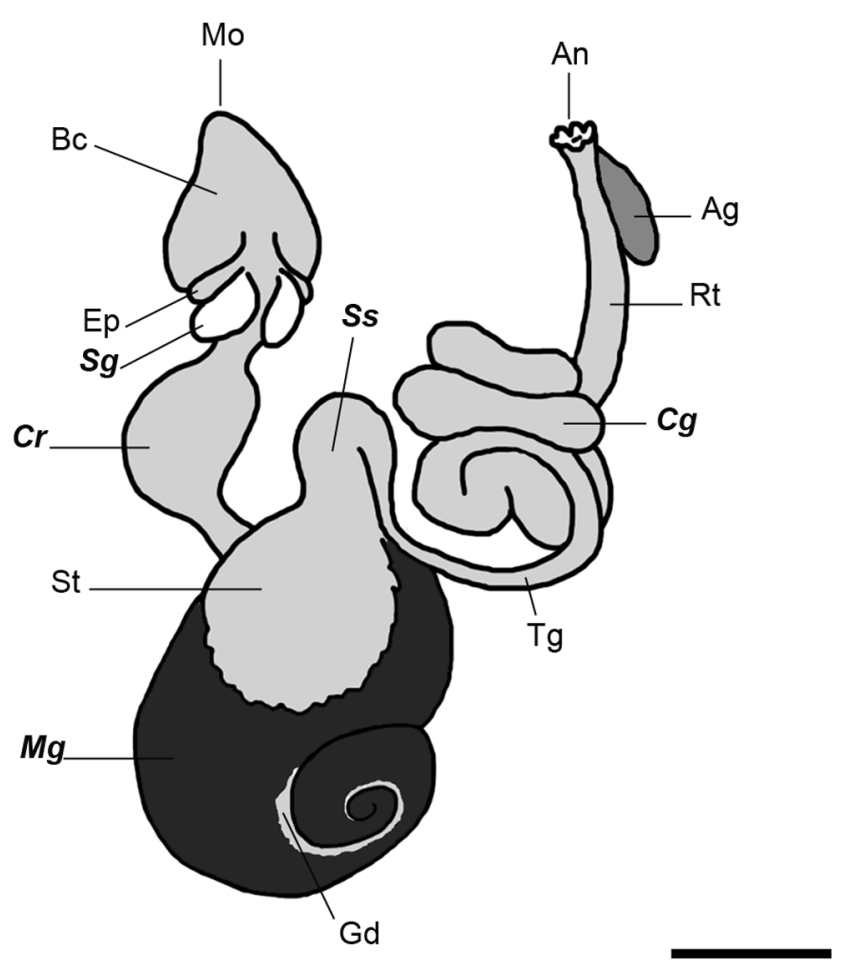

Figure 1. Schematic view of the digestive system of Pomacea canaliculata. In aboral order: mouth (Mo), buccal cavity (Bc), esophagic pouches (Ep), salivary glands $(S g)$, crop $(C r)$, stomach $(S t)$, midgut gland $(M g)$ with gonad $(\mathrm{Gd})$, style sac $(S s)$, thin gut $(\mathrm{Tg})$, coiled gut $(C g)$, rectum (Rt), anal gland (Ag) and anus (An). Bold italic letters indicate the sampled tissues and luminal contents. Scale bar $=1 \mathrm{~cm}$. doi:10.1371/journal.pone.0066689.g001

otherwise indicated, animals were fed ad libitum with lettuce from Monday through Friday and this was supplemented with high protein fish food pellets $(40 \%$ total protein content; Peishe Car Shulet ${ }^{\circledR}$, Argentina) on Thursday and with excess toilet paper on Friday.

\section{Luminal Protease Activity}

Snail acclimation. Animals were acclimated to feed exclusively on fish food pellets for $48 \mathrm{~h}$, after which they were fasted for $24 \mathrm{~h}$. After fasting, each animal was isolated in a vessel containing $70 \mathrm{~mL}$ water and 3 food pellets; $90 \mathrm{~min}$ after the first pellet was swallowed, each animal was immersed in an ice bath during 10 min to minimize pain and then the shell was cracked and the samples were obtained. The fish food pellets were approximately cubical ( $\sim 2.5 \mathrm{~mm}$ wide) and each one could be swallowed at once by the snails, without any visible fragmentation or spilling. The snails consumed all the offered food pellets during the $90 \mathrm{~min}$ period preceding ice-bathing.

Sampling. Immediately, after shell removal, an autostatic forceps was fixed on the posterior esophagus to prevent any passage of contents between the crop and the stomach during sampling. The crop and the style sac contents were collected with a $1 \mathrm{~mL}$ syringe by puncturing the walls with an 18-gauge needle. The coiled gut content was collected by gentle squeezing the sectioned gut.

For protein extraction, samples from the crop, style sac and coiled gut contents and of 3 snails were thoroughly dispersed in $750 \mu \mathrm{l}$ of an extraction buffer $(100 \mathrm{mM}$ Tris-HCl, $7.5 \mathrm{mM} \mathrm{NaCl}$,

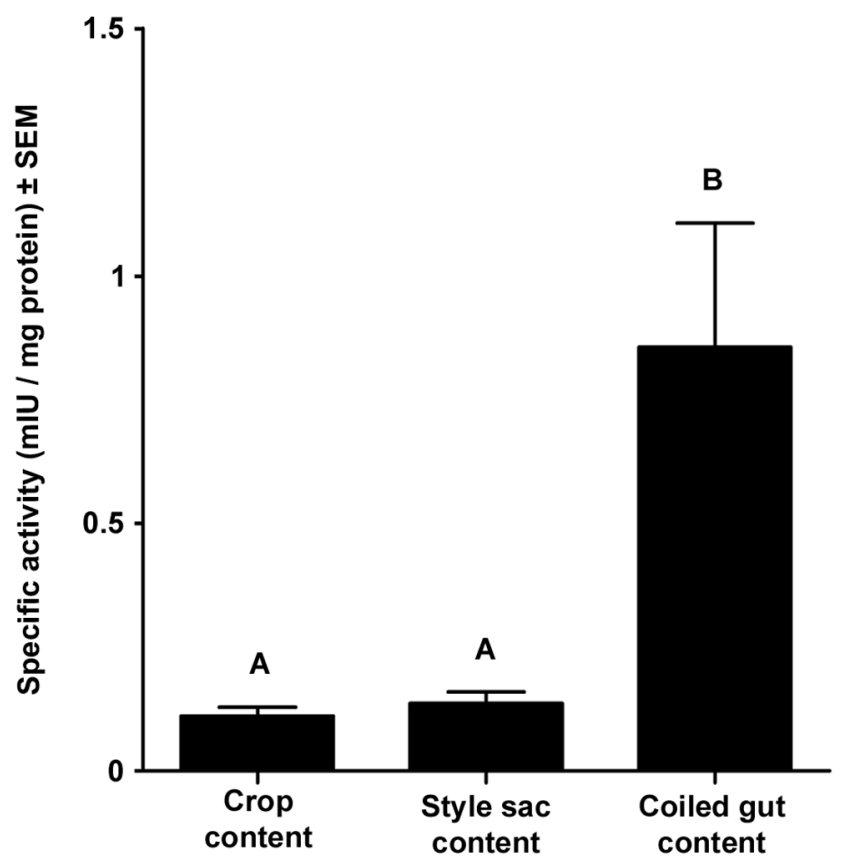

Figure 2. Specific protease activity in extracts of digestive tract contents. Different letters indicate statistically significant differences between groups (mean $\pm \mathrm{SEM}, \mathrm{N}=10$, Kruskal -Wallis test followed by Dunn's test, $\mathrm{p}<0.05)$.

doi:10.1371/journal.pone.0066689.g002

$0.25 \%$ Triton $\mathrm{X}-100, \mathrm{pH} 7.4$ ), centrifuged at $10000 \mathrm{~g}$ for $15 \mathrm{~min}$ at $4^{\circ} \mathrm{C}$, and the supernatants were kept at $-80^{\circ} \mathrm{C}$ until use.

Protease activity. Protease activity was determined in the thawed extracts $(\mathrm{N}=10)$ by spectrophotometry of the colored components generated by digestion of azocasein [23]. Hundred $\mu \mathrm{L}$ of protein extracts (crop content $=10.5-60 \mathrm{mg} \operatorname{protein} / \mathrm{mL}$; style sac content $=10.9-56.6 \mathrm{mg}$ protein $/ \mathrm{mL}$; coiled gut content $=4.6-11 \mathrm{mg}$ protein $/ \mathrm{mL}$ ) were mixed with $100 \mu \mathrm{L}$ of a reaction buffer $\left(0.5 \mathrm{M}\right.$ Tris-HCl, $2 \mathrm{M} \mathrm{NaCl}$ and $0.05 \mathrm{M} \mathrm{CaCl}_{2}$, $\mathrm{pH} 7.4), 500 \mu \mathrm{L}$ of $2.5 \%$ azocasein as substrate and completed with sterile bidistilled water to final volume of $1 \mathrm{~mL}$. The incubation conditions were $25^{\circ} \mathrm{C}, \mathrm{pH} 7.4$ and $24 \mathrm{~h}$, unless otherwise indicated. A mix of reagents without sample was used for blanks. The reaction was stopped with $500 \mu \mathrm{L}$ of $5 \%$ trichloroacetic acid and centrifuged at $10000 \mathrm{~g}$ for $10 \mathrm{~min}$. The supernatant obtained was diluted $(1: 1 ; \mathrm{v} / \mathrm{v})$ in $2 \% \mathrm{NaOH}$ and read at $440 \mathrm{~nm}$ in a Helios ${ }^{\circledR}$ Gamma spectrophotometer. Protein concentration in samples was determined according to the Lowry method [24] and specific protease activity was expressed as international milliunits per milligram of protein $(\mathrm{mIU} / \mathrm{mg}$ protein) using the Lambert-Beer equation and the azocasein $\mathrm{E}^{1 \%}$ coefficient supplied by the manufacturer.

Also, azocasein fragments resulting from digestion $(1 \mathrm{mg}$ protein per sample) were revealed by polyacrylamide gel (15\%) electrophoresis using Mini Protean II gel system (Bio-Rad Laboratories, Inc). Electrophoresis was performed according to Sambrook et al. [25] but the samples were processed under cold and non-reducing conditions (i.e., not treated with $\beta$-mercaptoethanol or dithiothreitol). After protein digestion, $5 \mu \mathrm{L}$ of reaction mixture (containing $5 \mu \mathrm{g}$ of luminal content and $62.5 \mu \mathrm{g}$ azocasein substrate) were diluted in loading buffer $(50 \mathrm{mM}$ Tris- $\mathrm{HCl}, 2 \%$ SDS, $0.1 \%$ bromophenol blue and $10 \%$ glycerol, $\mathrm{pH}$ 6.8). Also, azocasein substrate $(62.5 \mu \mathrm{g})$ and extracts of luminal contents $(5 \mu \mathrm{g})$ were loaded alone and used as controls. 


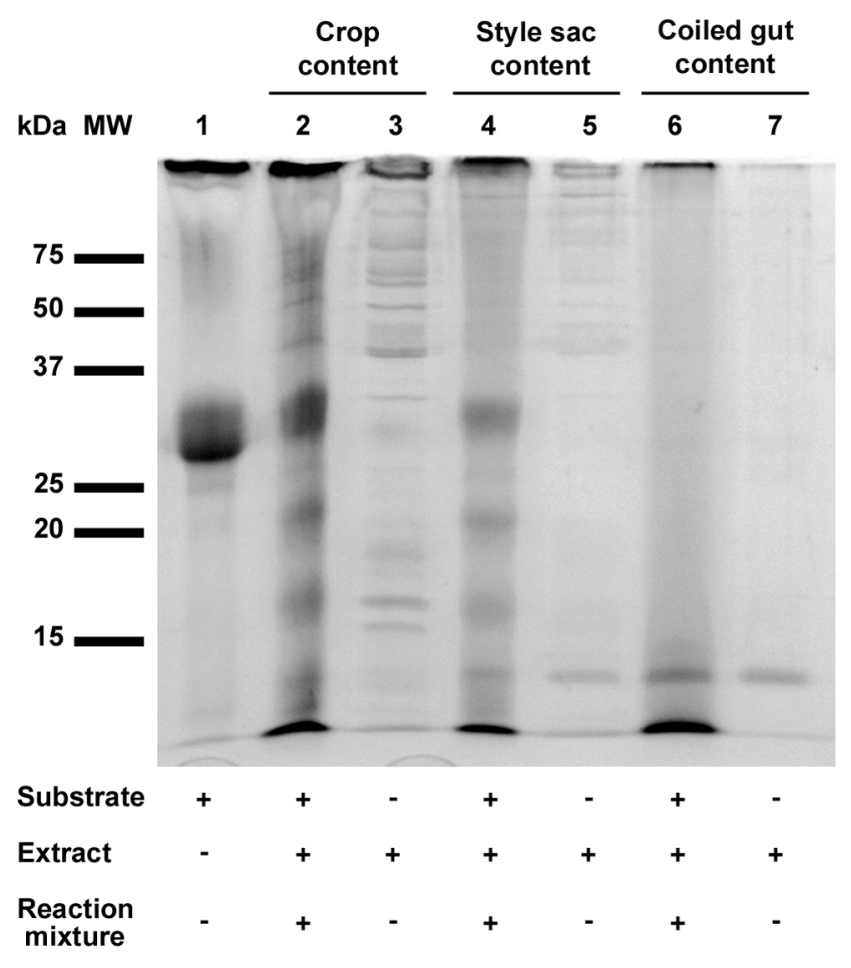

Figure 3. Azocasein digestion by extracts of crop, style sac and coiled gut contents. SDS-15\% polyacrylamide gel electrophoresis showing the digestion products of azocasein. MW: molecular weight markers. Azocasein substrate $(62.5 \mu \mathrm{g})$ was loaded in lane 1. Extracts of the different regions of the digestive tract ( $5 \mu \mathrm{g}$ proteins) were loaded in lanes 3,5 and 7 . The reaction mixture initially containing $62.5 \mu \mathrm{g}$ of azocasein and $5 \mu \mathrm{g}$ of protein in each extract were loaded in lanes 2,4 and 6.

doi:10.1371/journal.pone.0066689.g003

Each gel was run at $30 \mathrm{~mA}$ and was then stained with $0.75 \%$ Coomassie Brilliant Blue R-250 in a water-methanol-acetic acid solution $(45: 45: 10)$.

Also, exopeptidase activity was estimated by measuring the increase in free aminoacid concentration of the samples after digestion of bovine serum albumin (BSA, Sigma, A4503) with extracts of crop, style sac and coiled gut contents $(\mathrm{N}=5)$. Aminoacids were measured by the ninhydrin reaction [26,27]. For such purpose, $200 \mu \mathrm{L}$ of each extract were mixed with $10 \mu \mathrm{L}$ of $2 \% \mathrm{BSA}$ and were incubated at $35^{\circ} \mathrm{C}$ for $20 \mathrm{~min}$. The reaction was stopped with $1 \mathrm{~mL}$ of $1.2 \mathrm{M}$ trichloroacetic acid (TCA) and the mixture was centrifuged at $10000 \mathrm{~g}$ for $10 \mathrm{~min}$. Afterwards, $200 \mu \mathrm{L}$ of the supernatant were mixed with $100 \mu \mathrm{L}$ of $0.2 \mathrm{mM}$ $\mathrm{KCN}$ in $2 \mathrm{M}$ acetate buffer $(\mathrm{pH}=5.4)$ and $100 \mu \mathrm{L}$ of $1.75 \%$ ninhydrin (Sigma, N4876) in 100\% ethanol. Then the mixture was boiled for $10 \mathrm{~min}$ and chilled on ice for $1 \mathrm{~min}$ before the addition of $500 \mu \mathrm{L}$ of $50 \%$ ethanol. Measurements were made against a standard curve of L-leucine. Absorbance was read at $570 \mathrm{~nm}$ in a Helios Gamma spectrophotometer. Exopeptidase activity was expressed as $\mu \mathrm{mols}$ of aminoacids released $/ \mathrm{min}$ incubation $/ \mathrm{mg}$ protein (mean $\pm \mathrm{SEM})$.

\section{Diversity and Tissue Origin Of Luminal Proteases}

Acclimation and sacrifice of the animals, and the procedures for sampling the content of the crop, style sac and coiled gut were as described above. Also, both salivary glands and $\sim 100 \mathrm{mg}$ of the midgut gland and coiled gut tissue were obtained. For protein extraction, tissues were pooled (22 pools, 3 animals each) and homogenized in $750 \mu \mathrm{l}$ of the protein extraction buffer in an Ultraturrax ${ }^{\circledR}$ homogenizer. These extracts were used for zymographic determinations of apparent molecular weights.

Zymography was made in $10 \%$ polyacrylamide gels that were copolymerized with gelatin (Sigma G7765; $1 \mathrm{mg} / \mathrm{mL}$ ) and $75 \mu \mathrm{g}$ of the extracted protein were loaded per lane and electrophoresis was run at $4^{\circ} \mathrm{C}$ under non-reducing conditions. The gelatinolytic activity was revealed according to Sang et al. [28] with minor modifications. Briefly, the gels were rinsed for $15 \mathrm{~min}$ in a $2.5 \%$ Triton X-100 solution followed by three washes in distilled water. Then the gels were pre-incubated in reaction buffer for $30 \mathrm{~min}$, after which the buffer was changed and the gel was incubated overnight in a metabolic shaker $\left(45 \mathrm{rpm}\right.$ at $\left.25^{\circ} \mathrm{C}\right)$. Gelatinolysis was revealed by Coomassie Brilliant Blue staining so that protease activity appeared as white areas over a blue background. The apparent molecular weight of proteases was estimated using a linear curve between the relative mobility and the log of different molecular weight markers $(20,29,45,66,97,116$ and $205 \mathrm{kDa}$; Sigma T9767, C2273, A7642, A7517, P4649, G8511, M3889 respectively). Apparent molecular weights were expressed as mean $\pm \mathrm{SD}$.

\section{Protease Activity in Endosymbiotic Corpuscles}

Since a $30 \mathrm{kDa}$ protease was found in extracts of the midgut gland and the style sac (that receives the outflow of the midgut gland containing the endosymbiotic corpuscles) the hypothesis of an endosymbiotic origin of this protease was tested. For such purpose, five pools ( 2 acclimated snails each) of isolated $\mathrm{C}$ and $\mathrm{K}$ corpuscles, midgut gland tissue and style sac content were made. Samples from tissues and contents were obtained as already

Table 1. Occurrence of proteases in the digestive tract ( $\%$ of cases, $N=22$ ).

\begin{tabular}{lllllll}
\hline & & & & & \\
\hline Proteases (kDa) & Crop content & Style sac content & Coiled gut content & $\begin{array}{l}\text { Midgut gland } \\
\text { tissue }\end{array}$ & $\begin{array}{l}\text { Salivary gland } \\
\text { tissue }\end{array}$ & Coiled gut tissue \\
\hline $\mathbf{2 8} \pm \mathbf{1}$ & 0 & 9 & 100 & 9 & 0 & 0 \\
$\mathbf{2 9} \pm \mathbf{1}$ & 0 & 0 & 0 & 0 & 0 & 95 \\
$\mathbf{3 0} \pm \mathbf{2}$ & 100 & 100 & 100 & 72 & 0 & 0 \\
$\mathbf{7 0} \pm \mathbf{2}$ & 0 & 0 & 0 & 0 & 77 & 0 \\
$\mathbf{1 2 5} \pm \mathbf{5}$ & 82 & 41 & 0 & 0 & 0 & 0 \\
$\mathbf{1 4 5} \pm \mathbf{5}$ & 0 & 0 & 86 & 0 & 0 & 0 \\
$\mathbf{1 9 8} \pm \mathbf{5}$ & 0 & 0 & 64 & & 0 & 0 \\
\hline doi:10.1371/journal.pone.0066689.t001 & & & &
\end{tabular}



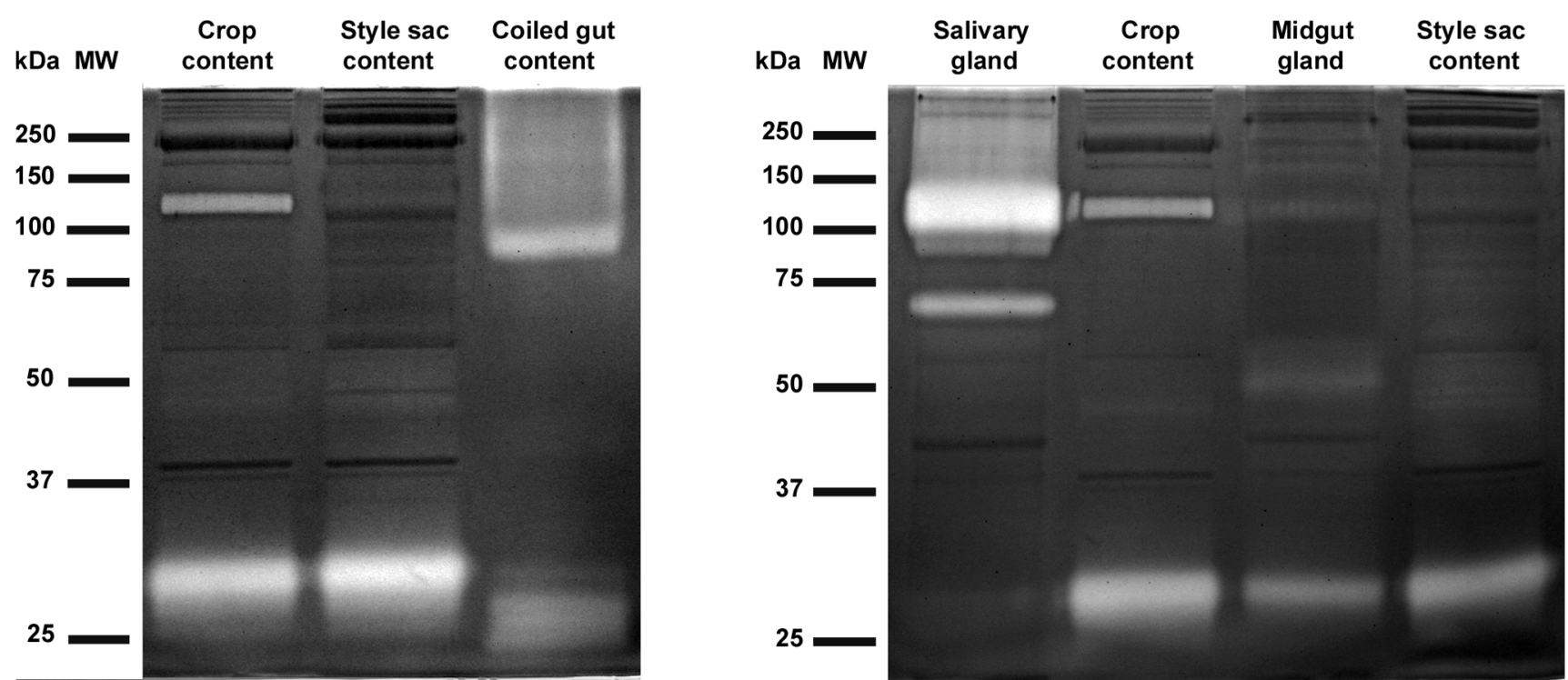

Figure 4. Diversity and tissue origin of digestive tract proteases. Zymographies (10\% polyacrylamide gels copolymerized with $1 \mathrm{mg} / \mathrm{mL}$ gelatin) showing protease activity (clear bands where gelatin was digested) and proteins with no protease activity (dark bands); Coomassie Brilliant Blue staining. (A) High and low molecular weight bands showing protease activity in digestive tract contents. (B) Correlative protease activity in salivary gland tissue and crop content, and in midgut gland tissue and style sac content. MW = molecular weight markers. Each lane was loaded with $75 \mu \mathrm{g}$ of protein.

doi:10.1371/journal.pone.0066689.g004

described, while the endosymbiotic corpuscles were isolated from $\sim 1 \mathrm{~g}$ samples of the midgut gland as previously reported [8]; the purity of fractions was microscopically controlled and only those $\mathrm{C}$ fractions containing less than $5 \%$ of $\mathrm{K}$ corpuscles, as well as those $\mathrm{K}$ fractions containing less than $1 \%$ of $\mathrm{C}$ corpuscles were used. The tissue and corpuscular samples were thoroughly crushed in a porcelain mortar using liquid nitrogen and then dispersed in

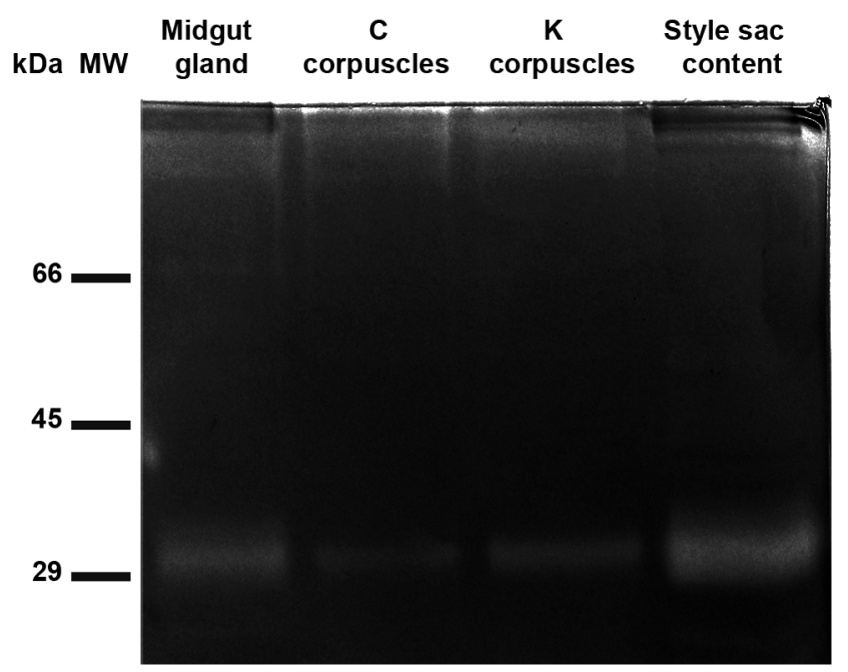

Figure 5. Endosymbiotic origin of the $30 \mathrm{kDa}$ protease. Zymography ( $10 \%$ polyacrylamide gel copolymerized with $1 \mathrm{mg} / \mathrm{mL}$ gelatin) of extracts of midgut gland, $\mathrm{C}$ and $\mathrm{K}$ corpuscles, and style sac content. $\mathrm{MW}=$ molecular weight markers. Each lane was loaded with $75 \mu \mathrm{g}$ of protein.

doi:10.1371/journal.pone.0066689.g005
$750 \mu \mathrm{l}$ of protein extraction buffer, centrifuged, and supernatant samples were processed for gel zymography.

\section{In situ Zymography}

Also, midgut gland samples for in situ protease zymography were obtained from acclimated snails. They were fixed in Beckstead's solution [29] and dehydrated through an ethanol series, embedded in paraffin and $5 \mu \mathrm{m}$ sections were obtained and processed for in situ zymography [30] using DQ-gelatin as substrate (D12054, Molecular Probes, Invitrogen). Tissue sections were deparaffinized in xylene, rehydrated in ethanol $96^{\circ}$ and bidistilled water, and placed in reaction buffer (see protease activity) for $10 \mathrm{~min}$ at room temperature. Then, each tissue section was preincubated in reaction buffer for $1 \mathrm{~h}$ at room temperature. Fifty microliters of a $20 \mu \mathrm{g} / \mathrm{mL}$ DQ-gelatin solution was then added to each slide and they were incubated for $2 \mathrm{~h}$ at $35^{\circ} \mathrm{C}$ in a humid chamber. The remaining substrate was then rinsed with bidistilled water and the sections was post-fixed in neutral buffered formalin $(4 \%$ formaldehyde, $0.33 \mathrm{mM} \mathrm{NaH} \mathrm{PO}_{4}, 0.45 \mathrm{mM} \mathrm{Na}_{2} \mathrm{HPO}_{4}, \mathrm{pH}=7$ ) for $20 \mathrm{~min}$. Finally, each section was rinsed for $5 \mathrm{~min}$ in phosphate buffer saline (PBS, $3.4 \mathrm{mM} \mathrm{NaCl}, 0.067 \mathrm{mM} \mathrm{KCl}, 0.25 \mathrm{mM}$ $\mathrm{Na}_{2} \mathrm{HPO}_{4}, 0.046 \mathrm{mM} \mathrm{NaH} \mathrm{PO}_{4}, \mathrm{pH}=7$ ) and mounted in glycerol-PBS $(90: 10 ; \mathrm{v} / \mathrm{v})$ containing $5 \mathrm{mg} / \mathrm{mL}$ propyl-gallate (P3130, Sigma) [31]. Similarly treated sections, but that were not exposed to the substrate were used as controls. The mounted sections were kept in darkness until epifluorescence was observed and photographed in Nikon Eclipse 80i Microscope using Nikon DS-Fil-U3 camera and Nikon NIS-ELEMENT Imagen Software for image acquisition. 
Table 2. Residual protease activity under different inhibitors.

\begin{tabular}{llllll}
\hline & & & & \\
\hline Intestinal contents & No inhibitor (control) & $\begin{array}{l}\text { Aprotinin (serine- } \\
\text { protease inhibitor) }\end{array}$ & $\begin{array}{l}\text { E64 (cysteine-protease } \\
\text { inhibitor) }\end{array}$ & $\begin{array}{l}\text { Pepstatin (aspartic- } \\
\text { protease inhibitor) }\end{array}$ & $\begin{array}{l}\text { EDTA (metalloprotease } \\
\text { inhibitor) }\end{array}$ \\
\hline Crop & 100 & $45 \pm 4^{*}$ & $125 \pm 18$ & $123 \pm 7$ & $117 \pm 3^{*}$ \\
Style sac & 100 & $38 \pm 3^{*}$ & $99 \pm 5$ & $108 \pm 5$ & $106 \pm 4$ \\
Coiled gut & 100 & $84 \pm 9$ & $100 \pm 8$ & $98 \pm 7$ & $78 \pm 6$ \\
\hline
\end{tabular}

Percent inhibition (mean \pm SEM) was calculated as residual protease activity in each group exposed to an inhibitor, divided by protease activity in the control group (without inhibitor) and multiplied by 100. N was 9 in each group. Ninety nine \% confidence intervals were used to assess the significance of differences (asterisks) from the control group.

doi:10.1371/journal.pone.0066689.t002

\section{Effects of Different Inhibitors on Luminal Protease Activity}

The effect of different inhibitors on protease activity was studied in contents of different parts of the digestive tract (crop, style sac, coiled gut). Nine pools of extracts were obtained as already described for each studied portion of the digestive tract. Hundred microliters of each pool (crop content $=10.5-60 \mathrm{mg} / \mathrm{mL}$; style sac content $=10.9-56.6 \mathrm{mg} / \mathrm{mL}$; coiled gut content $=4.6-11 \mathrm{mg} /$ $\mathrm{mL}$ ) were mixed with the following inhibitors dissolved in reaction buffer at the following final concentrations: $800 \mathrm{nM}$ aprotinin (serine-protease inhibitor, Sigma A1153), $10 \mu \mathrm{M}$ E64 (cysteineprotease inhibitor, Sigma E3132), $1.45 \mu \mathrm{M}$ pepstatin A (asparticprotease inhibitor, Sigma P5318) and $1 \mathrm{mM}$ EDTA (metalloprotease inhibitor, Sigma ED2SS) for $2 \mathrm{~h}$. Extracts without any inhibitor were used as control. Residual protease activity of each experimental group was expressed as \% of the protease activity observed in the control group (100\%).

Also, extracts of gut contents were obtained and the inhibition produced by each inhibitor (same concentrations above) was evaluated by gel zymography on the different protease bands.

\section{Effect of the $\mathrm{pH}$ and Temperature on Luminal Protease Activity}

Extracts of crop, style sac and coiled gut contents were used. Specific protease activity was determined at different $\mathrm{pH}$ values (10 pools, 3 acclimated snails each) and temperatures (7 pools, 3 acclimated snails each). Optimal $\mathrm{pH}$ range was determined by incubating the sample at $25{ }^{\circ} \mathrm{C}$ in the reaction buffer previously adjusted to $\mathrm{pH}$ values $5.5,6.6,7.5,8.5,9.5$ or 10.5 . The optimal temperature range was determined by incubating the sample at temperatures ranging from 18 to $40^{\circ} \mathrm{C}$, at $\mathrm{pH} 7.4$ for $24 \mathrm{~h}$. Protease activity was determined and expressed as percentage of the maximal observed activity.

For determining luminal $\mathrm{pH}$ values, samples of the luminal contents of crop, style sac and coiled gut from two acclimated animals were pooled, diluted in ASMT type I water $(1 / 25, \mathrm{v} / \mathrm{v})$ and $\mathrm{pH}$ was measured immediately at $24^{\circ} \mathrm{C}$ with a Beckman $\Phi 300$ pHmeter. Ten pools were used for determinations and mean $\mathrm{pH}$ values $( \pm \mathrm{SEM})$ were calculated for each digestive tract portion.
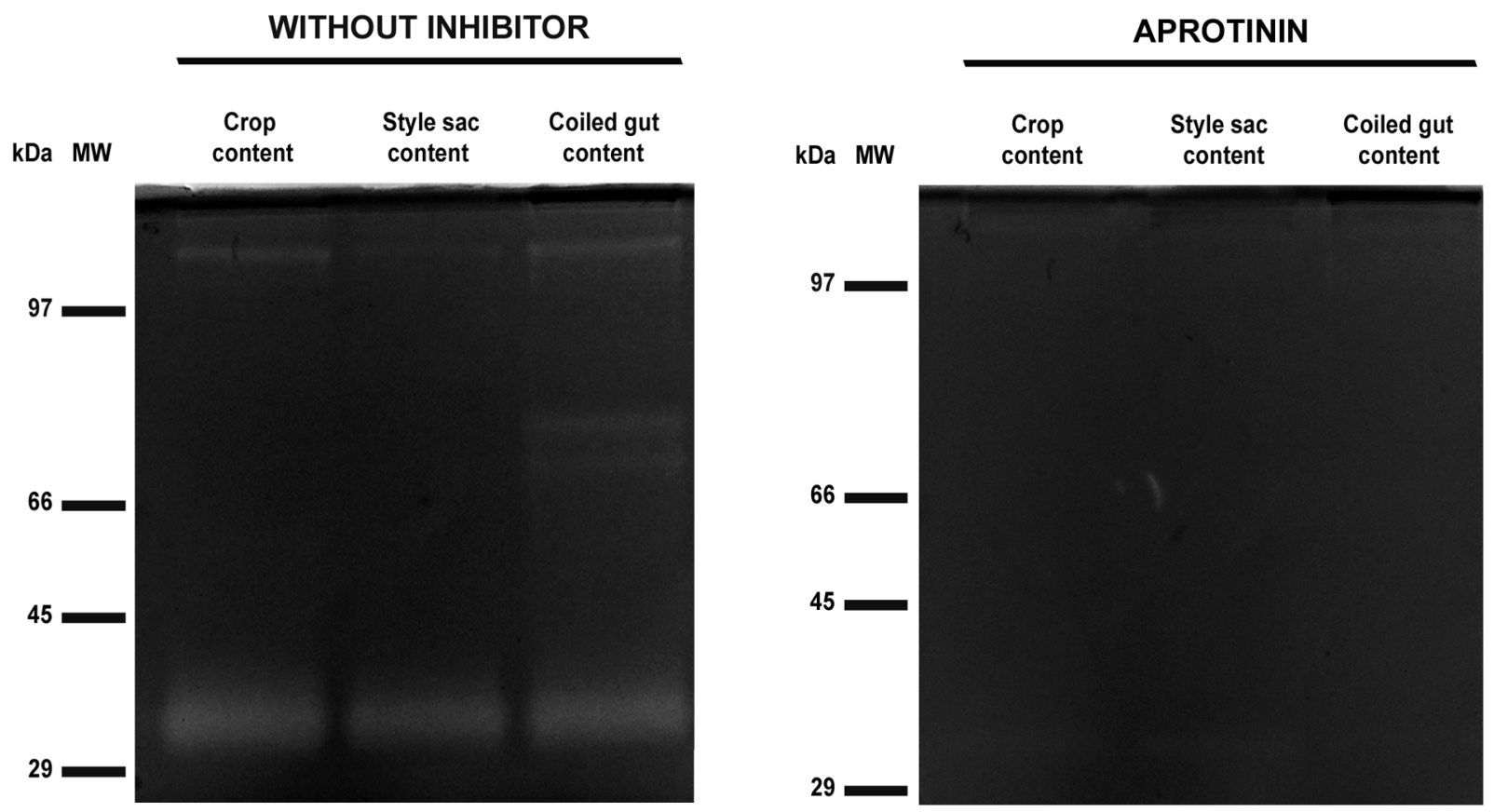

Figure 6. Inhibition of serine-proteases. Zymographies (10\% polyacrylamide gels copolymerized with $1 \mathrm{mg} / \mathrm{mL}$ gelatin) of contents of the crop, style sac and coiled gut that were incubated without or with aprotinin $(800 \mathrm{nM})$. MW: molecular weight markers. Each lane was loaded with $75 \mu \mathrm{g}$ of protein.

doi:10.1371/journal.pone.0066689.g006 

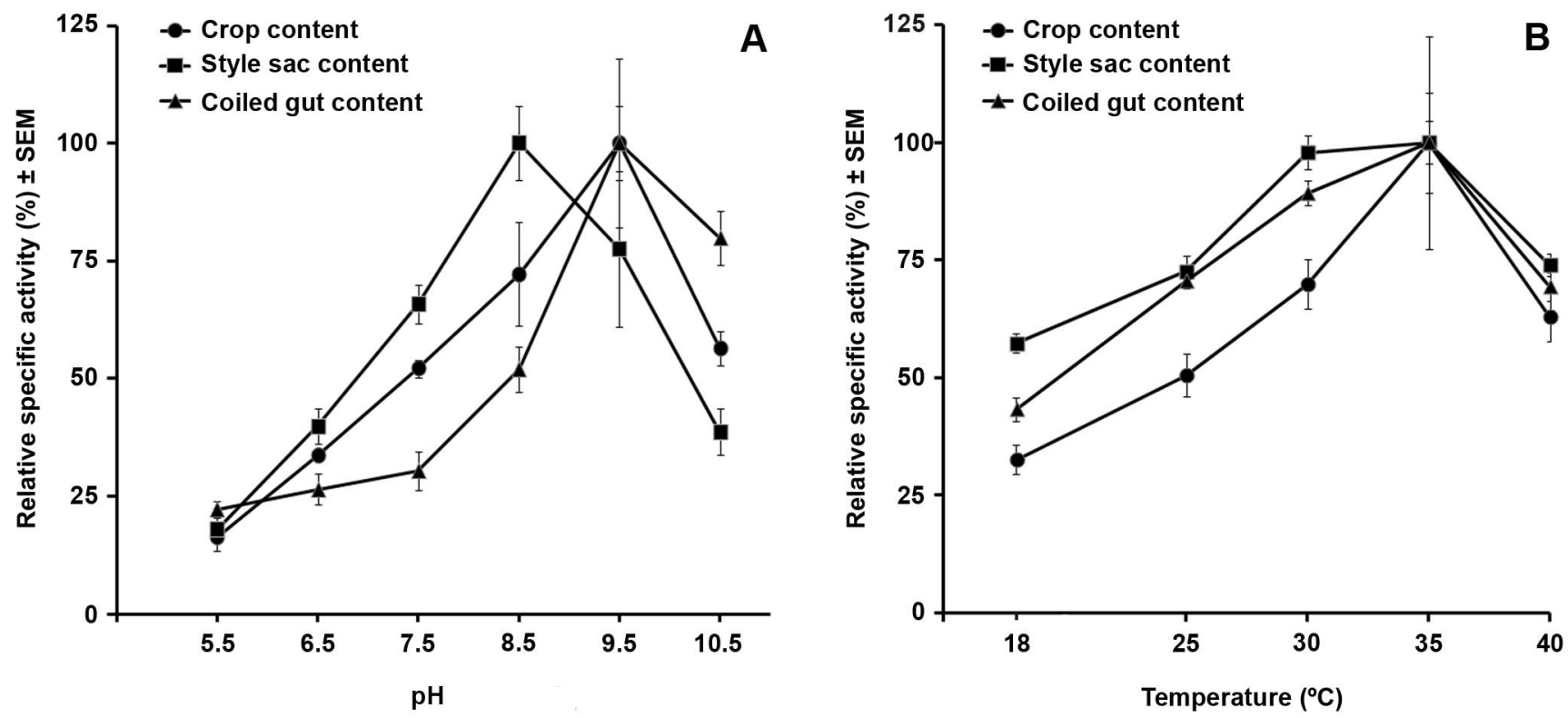

Figure 7. Optimal pH and temperature of protease activity in digestive tract contents. Specific protease activity of digestive tract contents at different $\mathrm{pH}(\mathbf{A})$ and temperature (B) values. Results were expressed as mean \pm SEM. $\mathrm{N}$ was 10 for $\mathrm{pH}$ determinations and 7 for temperature determinations.

doi:10.1371/journal.pone.0066689.g007

Tissue L-ala-N-aminopeptidase Activity in Portions of the Digestive Tract

Five pools of crop, style sac and coiled gut tissues, cleaned of its contents in HEPES-mannitol buffer $(1 \mathrm{mM}$ HEPES-KOH, $150 \mathrm{mM}$ mannitol, $\mathrm{pH}$ 7.6) were used to determine specific aminopeptidase activity according to Ciminari et al. [32]. Thawed samples $(20 \mu \mathrm{L})$ of each tissue extract were mixed with $1 \mathrm{~mL}$ of HEPES-mannitol buffer containing $2 \mathrm{mM}$ L-alanine-p-nitroanilide hydrochloride (Sigma, A9325) and incubated at $25^{\circ} \mathrm{C}$ for $20 \mathrm{~min}$ and then the reaction was stopped with $3 \mathrm{~mL}$ acetic acid. The standard curve was made using different dilutions of 4nitroaniline (Sigma, N2128). The absorbance of 4-nitroalinine released was read at $384 \mathrm{~nm}$ in a Helios Gamma spectrophotometer. Specific activity was expressed as international milliunits per milligram of protein. Results were expressed as mean \pm SEM.

\section{Statistical Analyses}

For multigroup comparisons, the distribution of variables was first evaluated by Kolmogorov-Smirnov's normality test, and equal variance Bartlett's test was used to evaluate homogeneity of variances for each set of experimental variables before applying one-way ANOVA and the Tukey test as a post-hoc analysis. Multigroup comparisons for specific protease activity (Figure 2) were made by Kruskal-Wallis test and Dunn's test as post hoc analysis, since the experimental groups presented unequal variances. Confidence intervals $(99 \%)$ were used to assess the significance of differences from the control group without inhibitors $(100 \%)$. All data analyses were performed using InfoStat ${ }^{\circledR}$, version 2009. Significance level was fixed at $\mathrm{p}<0.05$.

\section{Results}

\section{Luminal Protease Activity}

Protease specific activity was detected in luminal contents from all sampled regions of the digestive tract. Mean specific activity in the coiled gut was about 6-times higher than in the crop and the

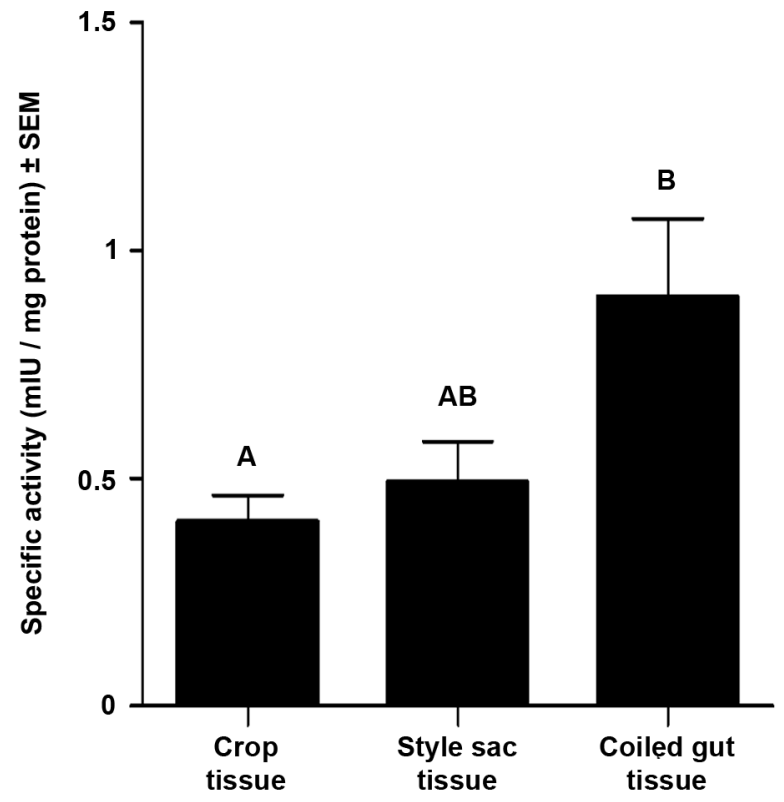

Figure 8. Specific L-alanine- $\mathrm{N}$-aminopeptidase activity in wall tissue of the crop, style sac, and coiled gut. Different letters indicate statistically significant differences between groups (mean \pm SEM, $N=5$, one way ANOVA followed by Tukey test, $p<0.05$ ). doi:10.1371/journal.pone.0066689.g008

style sac, and the differences were statistically significant (Figure 2, Kruskal-Wallis test). The fragmentation pattern of the azocasein substrate by luminal protease activity varied in the different digestive tract regions (Figure 3). The azocasein substrate was cut into four smaller fragments by the crop and style sac extracts 

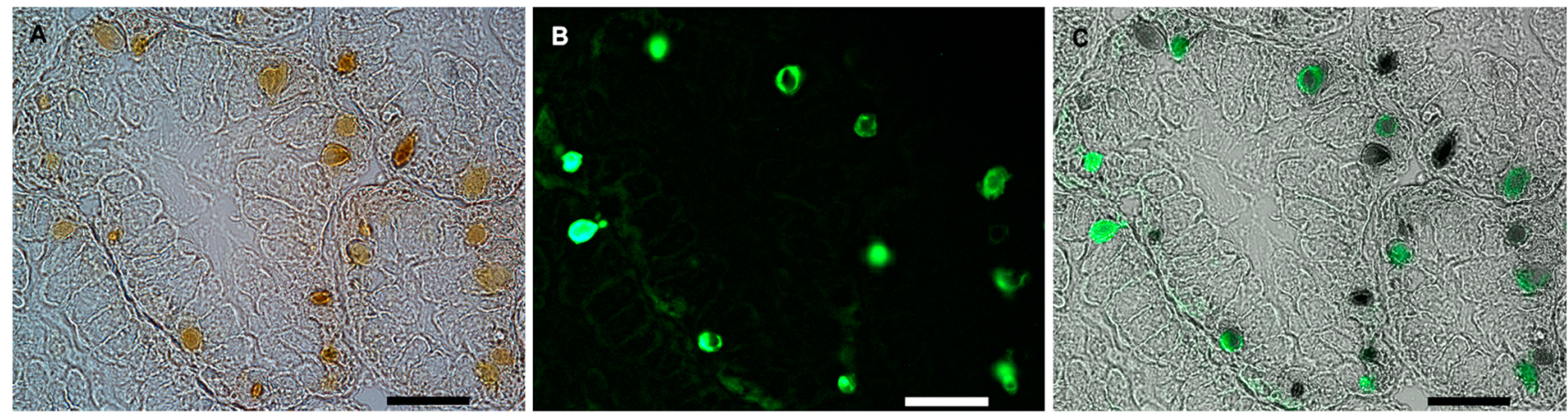

Figure 9. In situ zymography of midgut gland. A. Light microscopy of several tubulo-acini, showing numerous pigmented endosymbiotic corpuscles. B. Green fluorescence (FITC) indicates substrate degradation (DQ-gelatin). C. Merging of A and B showing substrate degradation by most endosymbiotic corpuscles. Corpuscles which do not show fluorescence may be either dead symbionts or, more likely, they may be the result of differences in the penetration of reagents. Scale bars $=50 \mu \mathrm{m}$. doi:10.1371/journal.pone.0066689.g009

indicating endopeptidase activity (Figure 3, lanes 2 and 4), while the substrate was completely digested by the coiled gut content (Figure 3, lane 6). However, this difference was not a consequence of the high activity present in this gut region, since a similar fragmentation pattern was observed when the assay was normalized by using the same specific activity to each lane (Figure S1).

Exopeptidase activity was detected in the crop, style sac and coiled gut content, but it was much higher in the latter $(3.5 \pm 1.3$; $4.6 \pm 1.1 ; 218.6 \pm 46.7$, respectively). Differences were significant between the coiled gut content and those of the other studied organs (one-way ANOVA, Tukey test).

\section{Diversity and Tissue Origin of Luminal Proteases}

The diversity and frequency of luminal protease bands is shown in Figure 4A and Table 1, respectively. A $30 \mathrm{kDa}$ protease band was the most frequently found in the lumen of the digestive tract. A $125 \mathrm{kDa}$ protease band was also present in extracts of the crop and style sac content in most snails but was always absent in the coiled gut. Two high molecular weight proteases (145 and $198 \mathrm{kDa}$ ) were only but frequently found in the coiled gut content.

A $28 \mathrm{kDa}$ protease band was found less frequently than the $30 \mathrm{kDa}$ protease, but always together with it, and also, a weak protease activity was sometimes found between $40-55 \mathrm{kDa}$ (Figure $\mathrm{S} 2)$.

Protease activity in tissue extracts (Figure 4B) suggests that the salivary gland is the origin of the $125 \mathrm{kDa}$ protease band, while the midgut gland is the origin of the ubiquitous $30 \mathrm{kDa}$ protease band and of the less frequent 28 and $40-55 \mathrm{kDa}$ ones. Salivary gland and coiled gut extracts showed frequently proteases of $70 \mathrm{kDa}$ (Figure 4B) and $29 \mathrm{kDa}$ (Figure S2), respectively, but it did not appear in the intestinal lumen.

The high molecular weight proteases found in the coiled gut lumen were not found in any of the extracts from salivary gland, midgut gland and coiled gut.

\section{Endosymbiotic Protease Activity}

Zymograms of extracts from midgut gland, $\mathrm{C}$ and $\mathrm{K}$ corpuscles and the style sac content (Figure 5) showed a protease band with an apparent molecular weight of $30 \mathrm{kDa}$ (five independent replicates were run). Also, a $45 \mathrm{kDa}$ protease band appeared in 2 of these cases in the style sac content, as well as two small and unusual $\sim 21$ and $\sim 23 \mathrm{kDa}$ protease bands (not shown in Figure 5).

\section{Inhibition of Luminal Proteases}

Results are shown in Table 2. Only the serine-protease inhibitor aprotinin caused a significant effect on total protease activity in the crop and style sac contents (99\% confidence intervals). Also, both aprotinin and EDTA produced some inhibition of total protease activity in the coiled gut, but the difference was not statistically significant.

The inhibitory effect of aprotinin on luminal digestive tract proteases was also shown in zymograms, since inhibition of each particular protease band (30, 125, 145 and $198 \mathrm{kDa})$ occurred in all studied portions of the digestive tract (Figure 6). However, no inhibition was observed in zymograms in presence of E64, pepstatin A or EDTA (Figure S3).

\section{Effect of the $\mathrm{pH}$ and Temperature on Luminal Protease Activity}

Total protease activity in the three studied portions of the digestive tract was maximal at alkaline $\mathrm{pH}$ values (8.5-9.5; Figure $7 \mathrm{~A}$ ) and at temperatures between $30^{\circ}-35^{\circ} \mathrm{C}$ (Figure $7 \mathrm{~B}$ ).

The $\mathrm{pH}$ values found in the luminal contents were: (a) crop, $5.96 \pm 0.09$, (b) style sac, 6.17 \pm 0.09 , and (c) coiled gut, 7.42 \pm 0.07 ) (mean $\pm \mathrm{SEM}, \mathrm{N}=11)$.

\section{Tissue L-ala-N-aminopeptidase Activity in Portions of the Digestive Tract}

Aminopeptidase specific activity in the wall tissue of the crop, style sac, and coiled gut is shown in Figure 8. Statistically significant differences were found between the crop and the coiled gut only.

\section{In situ Protease Activity in the Endosymbiosis and the Midgut Gland}

Fluorescence of degraded substrate (DQ-gelatin) is shown in sections of midgut gland tissue, indicating protease activity. A strong fluorescence signal was emitted by most endosymbiotic corpuscles (Figure 9) but only a very low signal was emitted by the surrounding cytoplasm of host cells. Sections which were not exposed to DQ-gelatin showed similarly low autofluorescence by the cytoplasm of host cells, but endosymbiotic corpuscles emitted no autofluorescence (not shown in Figure 9). 


\section{Discussion}

This is the first report of proteases in the digestive tract of ampullariid snails, since earlier authors had failed to detect any protease activity in the gut of ampullariids $P$. canaliculata and Pila virens $[4,17]$. However, the methods used to detect protease activity were not stated in those early publications.

A $30 \mathrm{kDa}$ serine protease (EC 3.4.21.) from endosymbiotic origin is the most frequently found in the lumen of the digestive tract in $P$. canaliculata. Also, another serine protease $(125 \mathrm{kDa})$ originated in the salivary glands of the host is found in the lumen of the crop and style sac. Furthermore, two high molecular weight serine proteases (145 and $198 \mathrm{kDa}$ ) of uncertain origin are found in the coiled gut lumen. And finally, L-ala-N-aminopeptidase activity (EC 3.4.11) is found in the wall tissue of the crop, style sac and coiled gut.

\section{Salivary Glands}

A pair of salivary glands is present in most gastropods and their ducts open into the buccal cavity and are thought to be involved in lubrication and agglutination of food [33]. Also, carbohydrases, proteases, lipases and phosphatases have been found in the saliva of herbivore and omnivore gastropods [10,34,35].

Two proteases (70 and $125 \mathrm{kDa}$ of apparent molecular weight) are found in the salivary glands of $P$. canaliculata but only the larger one is found in the crop lumen. The possibility that this protease were synthetized as a $70 \mathrm{kDa}$ subunit and that the secreted $125 \mathrm{kDa}$ protease were a dimer should await further investigation.

\section{Midgut Gland and Endosymbiotic Corpuscles}

The $30 \mathrm{kDa}$ protease is ubiquitously found in the digestive tract of $P$. canaliculata. It is present in extracts of both the midgut gland and the isolated endosymbionts, and activity (as determined by in situ zymography) is found in the latter. The endosymbionts are released through the midgut gland ducts into the stomach vestibule, and so a $30 \mathrm{kDa}$ protease activity is found downstream in the style sac and the coiled gut lumen. However, it is also found upstream in the crop content, which is explained by the lack of a sphincter separating the stomach from the posterior esophagus and, probably, by backward flux driven by pumping action of the muscular gizzard. The generation of four azocasein fragments by extracts of the crop and style sac contents suggests that both proteases, endosymbiotic of $30 \mathrm{kDa}$ and salivary of $125 \mathrm{kDa}$, are indeed endopeptidases.

Also, a $28 \mathrm{kDa}$ protease has been found together with the $30 \mathrm{kDa}$ protease in the coiled gut lumen. It has also been found in two cases in the style sac content and the midgut gland. It is possible that it is a large fragment resulting from partial digestion, but still retaining protease activity. Future research will have to clarify this point. A $45 \mathrm{kDa}$ protease was found in a few cases in both the midgut gland and the style sac content which may be either a short half-life protease or one that is rapidly inactivated during sample processing.

Even though $28-30 \mathrm{kDa}$ proteases have also been reported in other gastropods [36,37,38], bivalves [39,40] and cephalopods $[41,42]$ none of them has been attributed an endosymbiotic origin.

\section{Proteases in the Coiled Gut Lumen}

Total protease activity in the coiled gut lumen is much higher than in the lumen of the crop and the style sac (Figure 2). The high molecular weight proteases of 145 and $198 \mathrm{kDa}$ are only found in the coiled gut (Figure 3 and Table 1). High exopeptidase activity was also found in the coiled gut.
The origin of the 145 and $198 \mathrm{kDa}$ proteases is not clear, since they were not found either in coiled gut tissue or in extracellular bacteria grown in LB medium from samples of the coiled gut content (data not shown). Some possibilities should await future research: (a) that these proteases are produced and secreted in an inactive form; (b) that particular conditions of the coiled gut environment allow the expression of the 145 and $198 \mathrm{kDa}$ proteases by either the endosymbionts or the extracellular bacteria but that these conditions are not reproduced in vitro (LB medium). In this context, the possible role of intestinal bacteria (either probionts or not) in promoting digestion has attracted research in farmed abalones (Vetigastropoda) [43,44]. However, their quantitative significance as compared with that of host enzymes should await further studies, since a 98-99\% reduction of intestinal bacteria by antibiotics was generally unable to effectively reduce proteolytic activity in a pulmonate [45].

In addition the coiled gut tissue presents high L-ala-Naminopeptidase activity (Figure 8), indicating that it participates in the later stages of protein digestion. Also, a lower activity was found in the crop and style sac tissues. This is the first report of aminopeptidase activity in the digestive tract of an ampullariid snail, even though aminopeptidases are known to occur in the digestive tract of at least three vetigastropods (Haliotis fulgens, $H$. rufescens, [37] and Megathura crenulata [10], the littorinimorph Littorina irrorata [46] and the pulmonate Biomphalaria straminea [34].

\section{Proteases Characterization: Inhibitors and Optimal pH and Temperature}

All proteases found in the digestive tract of $P$. canaliculata were significantly inhibited by aprotinin (Table 2 and Figure 6), a broad-spectrum serine protease inhibitor [47]. The mean $\mathrm{pH}$ values found in portions of the digestive tract of $P$. canaliculata $($ crop $=5.96$, style sac $=6.17$, coiled gut $=7.42)$ are all below that of circulating hemolymph plasma [48] and would imply the existence of mechanisms for proton secretion into the gut of this snail.

It may be worth mention that similar, predominantly acidic $\mathrm{pH}$ values have been reported in the land pulmonates Helix pomatia (5.5-6.4), Helix aspersa, (6.1-7.4), Elona quimperiana (5.3-6.6) [14] and Arion ater (5.5-6.0) [11], and in the littorinimorph Littorina irrorata $(5.8-7.3)$ [46].

It is intriguing, however, that optimal specific protease activity in this study was found at higher $\mathrm{pH}$ values (style $\mathrm{sac}=8.5$, crop and coiled gut $=9.5$; Figure 7A). Also, the optimal temperature values $\left(30{ }^{\circ} \mathrm{C}\right.$ for the style sac content and $35^{\circ} \mathrm{C}$ for the crop and coiled gut contents, Figure7B) were only marginally overlapped with the thermal range of habitats occupied by Pomacea canaliculata $\left(10^{\circ} \mathrm{C}\right.$ to $\left.30^{\circ} \mathrm{C}\right)[49,50]$. Taken together, these data indicate that the proteases reported here are working effectively on dietary proteins at suboptimal conditions of $\mathrm{pH}$ and temperature.

\section{Conclusions}

Protease activity found in the contents of different digestive tract regions indicates that extracellular digestion of dietary proteins is significant in $P$. canaliculata. The sequential occurrence of endopeptidases and exopeptidases in the lumen, together with the occurrence of aminopeptidases in tissues, particularly in the coiled gut, may ensure the proper digestion and absorption of proteins in this polyphagous snail.

The existence and physiological role of the $30 \mathrm{kDa}$ endosymbiotic protease reported herein should also be studied in other ampullariid species in which similar pigmented corpuscles occur $[5,51,52]$ and suggest a possible functional role for these symbiotic association, which should be added to the detoxifying role of the 
endosymbiosis that have been proposed elsewhere [53]. Future studies on proteomics and genomics of the $30 \mathrm{kDa}$ protease could help to understand the phylogenetic relationships among the related endosymbionts in ampullariid snails.

\section{Supporting Information}

Figure S1 Azocasein digestion by extracts of crop, style sac and coiled gut contents. Extracts were diluted to obtain the same specific activity in all incubations. SDS$15 \%$ polyacrylamide gel electrophoresis showing the digestion products of $1.25 \%$ azocasein by $0.1 \mathrm{mIU} / \mathrm{mg}$ of each extract.MW: molecular weight markers. Azocasein substrate $(15 \mu \mathrm{L})$ was loaded in the first lane. Fifteen $\mu \mathrm{L}$ of each reaction mixture were loaded in lanes $2-4$

(TIF)

Figure S2 Proteases in the tissue and content of coiled gut. Zymography $(10 \%$ polyacrylamide gel copolymerized with $1 \mathrm{mg} / \mathrm{mL}$ gelatin) showing protease activity in a coiled gut content and tissue obtained after the acclimation of snails. MW $=$ molecular weight markers. Each lane was loaded with $75 \mu \mathrm{g}$ of protein.

\section{References}

1. Cowie R (2002) Apple snails (Ampullariidae) as agricultural pests: their biology, impacts and management. In: Baker G, editor. Molluscs as Crop Pests: Wallingford (CABI Publishing). 145-192.

2. Rawlings T, Hayes K, Cowie R, Collins T (2007) The identity, distribution, and impacts of non-native apple snails in the continental United States. BMC Evolutionary Biology 7: 97.

3. Oscoz J, Tomás P, Durán C (2010) Review and new records of non-indigenous freshwater invertebrates in the Ebro River basin (Northeast Spain). Aquatic Invasions 5: 263-284.

4. Andrews EB (1965) The functional anatomy of the gut of the prosobranch gastropod Pomacea canaliculata and of some other pilids. Proceedings of the Zoological Society of London 145: 19-36.

5. Castro-Vazquez A, Albrecht E, Vega I, Koch E, Gamarra-Luques G (2002) Pigmented corpuscles in the midgut gland of Pomacea canaliculata and other neotropical apple-snails (Prosobranchia, Ampullariidae): A possible symbiotic association. Biocell 26: 101-109.

6. Koch E, Vega IA, Albrecht EA, Ortega HH, Castro-Vazquez A (2006) A light and electron microcopic study of pigmented corpuscles in the midgut gland and feces of Pomacea canaliculata (Caenogastropoda, Ampullariidae). Veliger 48: 4552 .

7. Vega IA, Damborenea MC, Gamarra-Luques C, Koch E, Gueto JA, et al. (2006) Facultative and obligate symbiotic associations of Pomacea canaliculata (Caenogastropoda, Ampullariidae). Biocell 30: 367-375.

8. Vega IA, Gamarra-Luques C, Koch E, Bussmann LE, Castro-Vazquez A (2005) A study of corpuscular DNA and midgut gland occupancy by putative symbiotic elements in Pomacea canaliculata (Caenogastropoda, Ampullariidae). Symbiosis 39: 37-45.

9. Hernández-Santoyo A, Hernández-Arana A, Arreguín-Espinosa R, RodríguezRomero A (1998) Purification and characterization of several digestive proteases from the blue abalone, Haliotis fulgens. Aquaculture 159: 203-216.

10. Martin GG, Martin A, Tsai W, Hafner JC (2011) Production of digestive enzymes along the gut of the giant keyhole limpet Megathura crenulata (Mollusca: Vetigastropoda). Comparative Biochemistry and Physiology Part A: Molecular \& Integrative Physiology 160: 365-373.

11. Evans WAL, Jones EG (1962) A note on the proteinase activity in the alimentary tract of the slug Arion ater L. Comparative Biochemistry and Physiology 5: 223225.

12. Guionie O, Moallic G, Niamké S, Placier G, Sine JP, et al. (2003) Identification and primary characterization of specific proteases in the digestive juice of Archachatina ventricosa. Comparative Biochemistry and Physiology Part B: Biochemistry and Molecular Biology 135: 503-510.

13. James R, Nguyen T, Arthur W, Levine K, Williams DC (1997) Hydrolase ( $\beta$ glucanase, $\alpha$-glucanase, and protease) activity in Ariolimax columbianus (banana slug) and Arion ater (garden slug). Comparative Biochemistry and Physiology Part B: Biochemistry and Molecular Biology 118: 275-283.

14. Charrier M, Brune A (2003) The gut microenvironment of helicid snails (Gastropoda: Pulmonata): in-situ profiles of $\mathrm{pH}$, oxygen, and hydrogen determined by microsensors. Canadian Journal of Zoology 81: 928-935.

15. Cockburn T, Reid R (1980) Digestive tract enzymes in two Aeolid nudibranchs (opisthobranchia: Gastropoda). Comparative Biochemistry and Physiology Part B: Comparative Biochemistry 65: 275-281.
(TIF)

Figure S3 Zymograms of gut contents in presence of E64, pepstatin A or EDTA. Zymograms (10\% polyacrylamide gels copolymerized with $1 \mathrm{mg} / \mathrm{mL}$ gelatin) of contents of the crop, style sac and coiled gut contents that were incubated with or without $\mathrm{E} 64(10 \mu \mathrm{M})$, or pepstatin A $(1.45 \mu \mathrm{M})$, or EDTA (1 mM). MW: molecular weight markers. Each lane was loaded with $75 \mu \mathrm{g}$ of protein.

(TIF)

\section{Acknowledgments}

We thank Dr. Juan Chediack (IMIBIO-UNSL-CONICET, San Luis, Argentina) for training M.S.G. to perform the aminopeptidase assays.

\section{Author Contributions}

Conceived and designed the experiments: MSG ACV IAV. Performed the experiments: MSG IAV. Analyzed the data: MSG ACV IAV. Contributed reagents/materials/analysis tools: ACV IAV. Wrote the paper: MSG ACV IAV.

16. Biswas A, Ghose K (1968) Elaboration of enzymes in the digestive gland of Viviparus bengalensis (Mollusca: Gastropoda) during the first hours of digestion. Journal of Zoology 156: 325-332.

17. Meenakshi VR (1954) Studies on physiology of digestion in Pila virens Lamarck. Journal Animal Morphology \& Physiology 1: 35-47.

18. Hirata K, Aso Y, Ishiguro M (1998) Properties of $\alpha$-mannosidase partially purified from the apple snail, Pomacea canaliculata. Bioscience, Biotechnology, and Biochemistry 62: 2242-2245.

19. Hirata K, Aso Y, Ishiguro M (1998) Purification and some properties of $\beta$ mannosidase, $\beta$-N-acetylglucosaminidase, and $\beta$-galactosidase from apple snails (Pomacea canaliculata). Journal of the Faculty of Agriculture, Kyushu University 42: $463-472$.

20. Hirata K, Aso Y, Yasuda S, Ishiguro M (1998) Purification of Pomacea canaliculata $\alpha$-fucosidase isoforms with different thermostabilities. Bioscience, Biotechnology, and Biochemistry 62: 807-810.

21. Yamaura I, Koga T, Matsumoto T, Kato T (1997) Purification and some properties of endo-1, 4-beta-D-xylanase from a fresh-water mollusc, Pomacea insularus (de Ordigny). Bioscience, Biotechnology, and Biochemistry 61: 615620.

22. Imjongjirak C, Amparyup P, Sittipraneed S (2008) Cloning, genomic organization and expression of two glycosyl hydrolase family 10 (GHF10) genes from golden apple snail (Pomacea canaliculata). Mitochondrial DNA 19: 224-236.

23. Charney J, Tomarelli RM (1947) A colorimetric method for the determination of the proteolytic activity of duodenal juice. Journal of Biological Chemistry 171 : 501-505.

24. Lowry OH, Rosebrough NJ, Farr AL, Randall RJ (1951) Protein measurement with the Folin phenol reagent. The Journal of Biological Chemistry 193: 265275.

25. Sambrook J, Fritsch EF, Maniatis T (1989) Molecular Cloning: A Laboratory Manual: CSH Press.

26. Rosen H (1957) A modified ninhydrin colorimetric analysis for amino acids. Archives of Biochemistry and Biophysics 67: 10-15.

27. Ragster LE, Chrispeels MJ (1981) Autodigestion in crude extracts of soybean leaves and isolated chloroplasts as a measure of proteolytic activity. Plant Physiology 67: 104-109.

28. Sang QX, Dym M, Byers SW (1990) Secreted metalloproteinases in testicular cell culture. Biology of Reproduction 43: 946-955.

29. Beckstead JH (1995) A simple technique for preservation of fixation-sensitive antigens in paraffin-embedded tissues: Addendum. Journal of Histochemistry \& Cytochemistry 43: 345

30. Hadler-Olsen E, Kanapathippillai P, Berg E, Svineng G, Winberg JO, et al. (2010) Gelatin in situ zymography on fixed, paraffin-embedded tissue: zinc and ethanol fixation preserve enzyme activity. Journal of Histochemistry \& Cytochemistry 58: 29-39.

31. Longin A, Souchier C, Ffrench M, Bryon PA (1993) Comparison of anti-fading agents used in fluorescence microscopy: image analysis and laser confocal microscopy study. Journal of Histochemistry \& Cytochemistry 41: 1833-1840.

32. Ciminari ME, Moyano G, Chediack JG, Caviedes-Vidal E (2005) Feral pigeons in urban environments: dietary flexibility and enzymatic digestion. Revista Chilena de Historia Natural 78: 267-279.

33. Voltzow J (1994) Gastropoda: Prosobranchia. In Microscopic Anatomy of Invertebrates; Harrison F, Kohn A, editors. New York: Wiley-Liss, Inc. 111$252 \mathrm{p}$. 
34. Moura KRS, Terra WR, Ribeiro AF (2004) The functional organization of the salivary gland of Biomphalaria straminea (Gastropoda: Planorbidae): secretory mechanisms and enzymatic determinations. Journal of Molluscan Studies 70: 21-29.

35. Ghose KC (1961) Observations on the digestive enzymes and cellulolytic bacteria of the giant land snail Achatina fulica and their occurrence in the Gastropoda. Proceedings of the Zoological Society of London 137: 127-133.

36. Milne TJ, Abbenante G, Tyndall JDA, Halliday J, Lewis RJ (2003) Isolation and characterization of a cone snail protease with homology to CRISP proteins of the pathogenesis-related protein superfamily. Journal of Biological Chemistry 278: $31105-31110$

37. Garcia-Esquivel Z, Felbeck $\mathrm{H}$ (2006) Activity of digestive enzymes along the gut of juvenile red abalone, Haliotis rufescens, fed natural and balanced diets. Aquaculture 261: 615-625.

38. Picos-Garcia C, Garcia-Carreno F, Serviere-Zaragoza E (2000) Digestive proteases in juvenile mexican green abalone, Haliotis fulgens. Aquaculture 181: $157-170$.

39. Le Chevalier P, Sellos D, Van Wormhoudt A (1995) Purification and partial characterization of chymotrypsin-like proteases from the digestive gland of the scallop Pecten maximus. Comparative Biochemistry and Physiology Part B: Biochemistry and Molecular Biology 110: 777-784.

40. Reid RGB, Räucher K (1972) Protein digestion in members of the genus Macoma (mollusca: bivalvia). Comparative Biochemistry and Physiology Part A: Physiology 41: 887-895.

41. Balti R, Bougherra F, Bougatef A, Havet BK, Nedjar-Arroume N, et al. (2012) Chymotrypsin from the hepatopancreas of cuttlefish (Sepia officinalis) with high activity in the hydrolysis of long chain peptide substrates: Purification and biochemical characterization. Food Chemistry 130: 475-484.

42. Martínez R, Sántos R, Álvarez A, Cuzón G, Arena L, et al. (2011) Partial characterization of hepatopancreatic and extracellular digestive proteinases of wild and cultivated Octopus mava. Aquaculture International 19: 445-457.

43. Macey BM, Coyne VE (2006) Colonization of the gastrointestinal tract of the farmed South African abalone Haliotis midae by the probionts Vibrio midae SY9,
Cryptococcus sp. SS1, and Debaryomyces hansenii AY1. Marine Biotechnology 8: 246-259.

44. Zhao J, Shi B, Jiang QR, Ke CH (2012) Changes in gut-associated flora and bacterial digestive enzymes during the development stages of abalone (Haliotis diversicolor). Aquaculture 338: 147-153.

45. Walker AJ, Glen DM, Shewry PR (1999) Bacteria associated with the digestive system of the slug Deroceras reticulatum are not required for protein digestion. Soil Biology and Biochemistry 31: 1387-1394.

46. Bärlocher F, Arsuffi TL, Newell SY (1989) Digestive enzymes of the saltmarsh periwinkle Littorina irrorata (Mollusca: Gastropoda). Oecologia 80: 39-43.

47. Leung D, Abbenante G, Fairlie DP (2000) Protease inhibitors: current status and future prospects. Journal of Medicinal Chemistry 43: 305-341.

48. Cueto JA, Giraud-Billoud M, Vega IA, Castro-Vazquez A, Mendoza A (2011) Haemolymph plasma constituents of the invasive snail Pomacea canaliculata (Caenogastropoda, Architaenioglossa, Ampullariidae). Molluscan Research 31: 57-60.

49. Seuffert ME, Burela S, Martín PR (2010) Influence of water temperature on the activity of the freshwater snail Pomacea canaliculata (Caenogastropoda: Ampullariidae) at its southernmost limit (Southern Pampas, Argentina). Journal of Thermal Biology 35: 77-84.

50. Teo SS (2004) Biology of the golden apple snail, Pomacea canaliculata (Lamarck, 1822), with emphasis on responses to certain environmental conditions in Sabah, Malaysia. Molluscan Research 24: 139-148.

51. Devi CU, Rao KH, Shyamasundari K (1981) Observations on the histology and cytochemistry of the digestive gland in Pila virens (Lamarck)(Mollusca: Gastropoda). Proceedings: Animal Sciences 90: 307-314.

52. Meenakshi VR (1955) The excretory spherioles in the digestive gland of Pila virens. Journal Animal Morphology and Physiology (Bombay) 3: 75-78.

53. Vega IA, Arribere MA, Almonacid AV, Ribeiro Guevara S, Castro-Vazquez A (2012) Apple snails and their endosymbionts bioconcentrate heavy metals and uranium from contaminated drinking water. Environmental Science and Pollution Research 19: 3307-3316. 